\title{
Community Empowerment Through Milk Cow Cattle Logistic: in Collaborative Governance Perspective in Boyolali Regency of Central Java
}

\author{
Luluk Fauziah $^{1}$, Johan Bhimo Sukoco ${ }^{2}$, Suwandi ${ }^{3}$, Jatmika Prajayastanda ${ }^{4}$, and Anida Kurnia \\ $\mathrm{Umami}^{5}$ \\ \{ lulukfauziah@lecturer.undip.ac.id ${ }^{1}$, johanbhimo@lecturer.undip.ac.id ${ }^{2}$, suwandi@lecturer.undip.ac.id ${ }^{3}$, \\ jatmikaprajayastanda@lecturer.undip.ac.id ${ }^{4}$, Anidakurnia19@mail.com ${ }^{5}$ \} \\ Logistics Management and Administration Study Program, Vocational School Diponegoro University, \\ Semarang
}

\begin{abstract}
Community empowerment is an attempt of improving the quality of life. Building independency is a part of community empowering attempt. It is a sustainable process to build community's ability by encouraging, motivating, and generating consciousness of potency in order to be independent and to improve its standard of life. The objectives of research are to find out the process of empowering milk cow breeders and to identify its supporting and inhibiting factors. Collaborative governance is not given but builds on various aspects. It can be seen from the institution's need aspect to establish cooperation between institutions, because of each institution's limited ability to organize its program/activity itself. This study was descriptive qualitative research. The instrument of research was the author herself, with observation, interview, and documentation study. Data validation was conducted using data source triangulation technique. Data analysis was conducted through data reduction, data display, and conclusion drawing. The result of research showed that community empowerment through logistic reinforcement has not been conducted maximally yet. Partnership and cooperation between stakeholders in milk cow management has run sufficiently well. The supporting factor is that Boyolali Regency is very superior with milk cow breeder human resource, while the inhibiting factor is that the program of improving knowledge and training for milk cow breeder human resource is held only once a year because of limited budget existing.
\end{abstract}

Keywords: Empowerment, logistic, and collaborative governance

\section{Introduction}

Agricultural development basically aims to improve production toward self-sufficiency, to increase job opportunity, and to improve and to distribute the people's life standard evenly. To achieve those objectives, animal husbandry subsector mainly prioritizes, among others, milk cow breeding business development. Bustanul Arifin stated that animal husbandry-based agribusiness is one of phenomenon growing rapidly when the farm base has been limited. The demand for integrated farming system becomes more rational along with the demand for the efficiency and effectiveness of land, labor, capital and other very limited production factor uses. Cow milk breeding business is a business with advance characteristic, using new technology 
selectively so that can improve production proportionally but in practice the cattle breeders do not understand fully the technology use. One of big challenges encountered by animal husbandry sector is the fairly low consumption rate of milk-made animal protein, 4.3 $\mathrm{kg}$ /capita/year, compared with the attempt of to improve the consumption of milk-made animal protein, $5 \mathrm{~kg} /$ capita/year.

Community empowerment is an attempt of improving life quality of all society members. Building the milk cow breeders' independency is a part of community empowerment attempt. Many attempts have been taken by milk cow breeders to improve independency, and good creative idea utilization is very desirable to be a solution to enable the people to run milk-cow breeding business successfully. Milk cow breeders should be able to achieve independency and the best way of achieving the improved family economy. The people raising the milk- cow more independently highly affect the life independency condition. Independency is a condition of standing alone, not dependent on others.

Community empowerment is a sustainable process to build the people's ability by means of encouraging, motivating, and to generate the awareness of potency, in order to be independent and to improve their standard of life. Community empowerment is an attempt of improving the quality of society life. The development strategy in cow breeding has a good prospect in the future, because the demand for materials coming from cattle will increase continuously along with people's demand, income, and awareness of consuming nutritious food. However, many constraints are still encountered in cow breeding: HR quality in cow breeder group, people's and cow breeders' inadequate knowledge. In addition, program and activity held in the attempt of empowering the community are still limited in number. The program implemented in Boyolali Regency emphasizes more on farming and cow breeding sector. The community empowerment in health and education sectors has not been developed optimally. The number of potential owners and cattle increases over years in Boyolali Regency, as shown in the table below.

Table 1. Number of Owner and Cattle in Boyolali Regency (2017-2019)

\begin{tabular}{ccccccc}
\hline Commodity & \multicolumn{3}{c}{$\mathbf{2 0 1 7}$} & \multicolumn{2}{c}{$\mathbf{2 0 1 8}$} & \multicolumn{2}{c}{$\mathbf{2 0 1 9}$} \\
\cline { 2 - 6 } & People & Cows & People & Cows & People & Cows \\
\cline { 5 - 8 } & & & & & & \\
Beef Cattle & 42,894 & 96,066 & 43,182 & 99,311 & 43,128 & 106,599 \\
Milk Cow & 27,060 & 92,619 & 27,055 & 92,856 & 27,048 & 94,088 \\
Buffalo & 251 & 787 & 247 & 745 & 244 & 749 \\
\hline
\end{tabular}

Source: Boyolali in Number, 2020

The context of vulnerability as the risk aspect of milk cow breeding business still becoming frightening specter includes, among others: 1) season is an uncertain natural condition, 2) security is the cattle stealing level, 3) cattle disease, 4) fluctuating milk price at national and local levels, 5) government policy, 6) cattle breeder group policy or institution, and 7) cattle breeder group morality [11]. Cattle breeder group's morality determines the dynamic of cattle breeder group as a form of institution. The dynamic of cattle breeder group is affected by: 1) cattle breeder group's infrastructure, 2) the achievement of cattle breeder group's objective, 3) function and duty of cattle breeder group, 4) cattle breeder group's structure, 5) cattle breeder group's concord, and 6) form of cattle breeder's institution. The form of cattle breeder's institution can affect the milk cow breeding business in Indonesia. The successful development of cattle breeding business can be seen from, among others: 1) 
the increase in cattle breeders' income, 2) the increase in the population of cattle raised, 3) the increased in the number of paid workers, and 4) the increase in production units or cattle stall. The development of milk cow breeding business in supporting national development is compatible to 1) RPJMN 2015-2019, 2) Minister of Agriculture's Regulation Number 100 of 2014, 3) National Strategy Plan in 2015-2019, and 4) Minister of Agriculture's Regulation Number 55 of 2006. Considering the elaboration above, this research aims to describe the community empowerment process through reinforcing the milk cow breeding logistic and to describe the factors supporting and inhibiting the milk cow breeding in collaborative governance perspective in Boyolali Regency, Central Java.

\subsection{Literature Study \\ Previous Studies}

A study entitled "Sanitasi Kandang dan keluhan kesehatan pada peternak sapi perah di desa Murukan Kabupaten Jombang (Stall Sanitation and health-related complaint in milk cow breeders in Murukan Village of Jombang Regency)" was conducted by Rizqi Zuroida and R. Azizah in 2018. This study found that milk cow breeders are risky of being affected adversely by the not- well-managed milk cow waste because the breeders have direct contact daily with the waste. Milk cow manure containing some microorganism, gas, and other organic materials can be agent of disease in human beings. The objective of research is to analyze the relationship of stall sanitation including stall location, stall building construction, stall cleanliness and fly density to the health-related complaint perceived by the cattle breeder during working in the stall. The result of research showed that there is no relationship between stall sanitation and health- related complaint perceived by breeders during working in the stall $(p=0.710)$. Another study entitled Perencanaan Lanskap Kawasan Penerapan Inovasi Teknologi Peternakan Prumpung Berbasis Ramah Lingkungan (Design of Animal Husbandry Technology Innovation Application Area Landscape (KAPITAN) based on Environment Friendliness) was conducted by Djatmiko Pinardi, Anton Gunarto, Santoso in 2019. This study found that KAPITAN is an animal husbandry area that will apply GFP consistently in the attempt of improving ruminant cattle production through improving its population and productivity nationally. KAPITAN landscape design is manifested into site plan dominated with geometrical pattern composed of site elements including plant disease and pest and its thematic filler plant. Zonation is developed, including: public Zone (4\%), recreation zone (9\%), production zone (81\%), and private zone $(6 \%)$. The site constraint lies on the physical factors that still can be minimized. KAPITAN is an animal husbandry area with the basic characteristic of an environmentfriendly-based concept with integrated model of plant and cattle, in which there is an interrelationship between green plants for cattle feed, cattle waste in the form of liquid bioslurry as biogas (energy), while the solid waste can be used as organic fertilizer. This zero waste approach can be utilized and processed thereby having economic value.

A study entitled Pengembangan Usaha Ternak Sapi Perah: Evaluasi Konteks Kerentanan Dan Dinamika Kelompok (The Development of Milk Cow Breeding Business: An Evaluation on the Context of Group Vulnerability and Dynamic) was conducted by Amam and Pradiptya Ayu Harsita in 2019. This study found that the milk cow breeding business has strategic value in supporting the animal husbandry subsector of agricultural development to satisfy the ever increasing need for food source coming from cattle, i.e. milk, as the result of population growth. The objective of study was to find out the milk cow breeding business development model based on the context of group's vulnerability and dynamic. The result of research showed that: a) vulnerability context affects negatively and significantly the development of milk cow cattle breeding business, b) group dynamic affects positively and 
significantly the development of milk cow breeding business, and c) vulnerability context affects negatively and significantly the dynamic of milk cow breeder group.

The difference between three previous studies and the research currently conducted by the author lies on the problem studied, in which the author emphasizes on community empowerment through strengthening milk cow breeding logistic in collaborative governance perspective, while Rizki Zuroida (2018) emphasized on stall sanitation and health-related complaints perceived by cow milk breeders. In addition, the study conducted by Djatmiko Pinardi et al (2019) is related to the landscape of Prumpung animal husbandry technology innovation application area based on environment friendliness. Meanwhile, the research conducted by Amam and Pradiptya Ayu Harsita (2019) studied the development of milk cow breeding business: an evaluation on the Context of Group Vulnerability and Dynamic. This current research's novelty is that no similar study focusing on the reinforcement of milk cow breeding logistic related to collaborative governance.

\section{Community Empowerment Concept}

Empowerment, according to David Korten [8], is defined as action to reduce the dependence through some measures that can improve the potency of poor people to take independent and beneficial political action on behalf of them. Meanwhile, Chatarina Rusmiyati (2011) [4] stated that empowerment is how people, organization, and community are directed in order to master their life, or empowerment is considered as a process of making people fairly strong to participate in events and institutions affecting their life.

Whereas, Winarni [2] suggested that empowerment involves 3 (three) matters: enabling, empowering, and therefore creating independency. Departing from those opinions, it can be said that empowerment occurs not only in the people with no capability but also in those with still limited power, in order to be developed to achieve independency.

Tricahyono (2008)[10] stated that the principles of empowerment are as follows: a) the development conducted should be local in nature; b) emphasizing more on social action; c) using community organization or local community approach; d) equality in work relation; e) using participation approach, the members of group serve as subject rather than object, and f) social welfare effort for justice.

Meanwhile, Kindervatter [10] suggested that community empowerment has the following characteristics: a) composed of small groups; b) transfer of responsibility; c) leadership by partisans; d) agent as facilitator; e) democratic process and non-hierarchical work relation; f) integration between reflection and action; g) method used leads more to the development of self-confidence; and h) an attempt of improving social, economic, and political independence degree.

Referring to Alsop [1], community empowerment can be measured through asset endowments or opportunity structure. Considering asset endowmentll, World Bank measures indicator of community empowermentbased on World Bank's Living Standards Measurement Survey (LSMS)'s data including, among others, human capital, social capital, and access to productive assets. 
Table 2. Indicators of community empowerment

\begin{tabular}{ccc}
\hline \multicolumn{1}{c}{ Asset } & Indicator & Instruments \\
\hline $\begin{array}{c}\text { Psychological } \\
\text { assets }\end{array}$ & $\begin{array}{c}\text { Individual's ability of dealing } \\
\text { with the change process } \\
\text { Access to information media } \\
\begin{array}{c}\text { Informational } \\
\text { assets }\end{array}\end{array}$ & $\begin{array}{c}\text { IQMSC } \\
\text { IQMSC }\end{array}$ \\
& & QMSC \\
Organizational & & \\
assets & Affiliation with organization & LSMS \\
Material assets & Land Ownership Community's & Household Budget \\
Financial assets & saving ability & Survey \\
Human assets & Literacy & LSMS education motode
\end{tabular}

Source: Alsop et al., 2006 [1]

Notes:

IQMSC : Integrated Questionnaire for the Measurement of Social Capital.

QMSC : Questionnaire for the Measurement of Social Capital.

LSMS : Living Standards Measurement Study.

\section{Empowerment Process}

Community empowerment is the objective of the program of developing an instrument to achieve the objective of development [1]. Meanwhile, according to Gonzaga et al. (1994) as citedin Eusebio (2003), community empowerment consists of some process: community organization, credit aid, training capacity building, technology access and advocacy help.

\section{a) Community Organizing}

Community Organizing refers to the establishment of community organization to solve problem and to prioritize cooperation between members. Community organizing (CO) organizes individuals or groups with varying thinking, need, and behavior. In $\mathrm{CO}$ there are organizational objective and procedure to be followed.

\section{b) Training}

In Nelson's (2006) opinion, an attempt taken by the donor countries to support the development in developing countries is to provide training and skills building programs. Education is the most important factor in community involvement and participation in development program. Training aims to improve knowledge and innovation in environmental change. 


\section{c) Building Network}

Dizon (1997) argued that an indicator of empowerment is networking. A Summit's ability of building network with other parties will, of course, benefit it and its members. The advantages of building network with other parties are among others, related to the effectiveness of knowledge and information exchange and that it encourages the sustainability of a Summit. . Fongmul (2006) explained that elaboration between farmer organizations will strengthen the relation to help solve the farmers' problem.

\section{Collaborative Governance Concept}

The theory used to see the actual relationship between government and community in managing milk-cow breeding is collaborative governance theory or cooperation in implementing governance. Emerson (2011) defined it as a process and structure of public policy and governance by involving community, private, NGOs, from many existing institutions and levels and to determine the collective objective that is difficult to formulate alone[5]. Meanwhile, Mc Guire (2006) explained that collaborative governance is a concept of government management as a facilitation and implementation process conducted by some institutions, whether government, community, or NGOs, aiming to solve the collective problem that cannot be solved by one governmental institution only [6].

Another paradigm concerning collaborative governance has been revealed by John Wanna (2008), defining cooperation as cooperating or working along with other parties, that is individual, group, or organizational in nature. Referring to Wildavsky (1973),Wanna (2008) suggested that cooperation involves some dimensions: firstly, cooperation in building togetherness, improving consistency, and straightening the activities between actors. Secondly, cooperation can serve as negotiation process as well, involving a preparation to compromise and to enter into agreement. Thirdly, it can also be collective anticipation to potential error to occur, through a set of rules. Fourthly, cooperation can also be power and compulsion, an ability of encouraging the outcome. Fifthly, cooperation includes commitment to the future and its intensity, planning or preparation to straighten activities to be done. Cooperation includes participation, internal motivation development process, and personal commitment to the project to be done.

Another perspective is suggested by Chris Ansell and Alison Gash (2008) [3] stating that collaborative governance is public governance in which the governmental institutions involve directly the actors beyond the government (community, NGOs, and private sector) in formal decision making process, oriented to collective interest. It is intended to implement the policy and to manage program and resource jointly. From this perspective, according to Ansell and Gash (2008) [3], there are some important keywords to be noted: (1) cooperation initiated by government institution, (2) non-government actor participation, (3) all actors participate policy making process, (4) cooperation forum is organized and designed collectively, (5) the objective of cooperation forum is to make decision collectively, and (6) the focus of cooperation is on policy making and public governance.

\section{Reason of Doing Collaborative Governance}

Generally, collaborative governance appears adaptively or deliberately created consciously for the following reasons: 1) complexity and interdependency between 
institutions; 2) conflict between interest group is latent in nature and difficult to muffle; 3) the attempt of looking for a new way of achieving political legitimacy. Law fragmentation and problem solving that are multi-jurisdiction in nature are two main sources or institution complexity and interdependency. Conflict between interest groups that is latent and difficult to muffle is often harmful to many parties, needs great effort and attention. Thus, without collaborative governance in problem solving, conflict between groups will be difficult to muffle. When many attempts have been taken but unfruitful, the collaboration can be made as an attempt of solving problem with strong legitimacy as it involves many interest groups to participate actively and to make decision jointly [3].

Meanwhile, the organization's reasons of doing collaborative governance are: firstly, social change, today is a community reform era and information phase leading the structure to disseminate to all scopes; and secondly, the problem dealt with by government today cannot be managed efficiently if it relies on one organization only. Government needs different mechanism and should be flexible. Collaboration between many sectors is made to solve problem (McGuire in Sabaruddin, 2015: 34).

\section{Model Collaborative Governance}

Collaborative Governance model, according to Ansel and Gash (2008)[3], consists of 4 (four) main variables:

1) Prior condition

The condition present in the beginning of collaboration can be facilitating or preventing cooperation between stakeholders, institutions, and shareholders. Stakeholders having bitter division history over some local emotional problems consider as enemy. Stakeholders have collective vision to be achieved through collaboration and past history of cooperation. The problem encountered is related to the imbalanced resource of some collaborating stakeholders.

a) Imbalanced resource. The problem often encountered by stakeholders in collaborative governance is imbalanced resource. If shareholders have no capacity, organizational status or resource to participate along with other stakeholders, collaborative governance process will be vulnerable to the manipulation by stronger actors.

b) Incentive to participate. Incentive improves between stakeholders and participation in the effective output out policy. Although collaborative approach is obliged by legislative council, the participation of shareholders is usually voluntary in nature. As a result, the incentive of stakeholders who should enter into collaboration is the factor explaining whether or not collaborative governance can be successful. Incentive of participation is low when stakeholders can achieve the objective unilaterally.

c) Prehistoric antagonism and cooperation. Stakeholders can see that they can achieve objective without participation in collaborative governance process. If prehistoric antagonism between stakeholders occur, collaborative program will not be successful, but with interdependency system between stakeholders.

\section{2). Institutional Design}

Institutional design is important to legitimize the collaborative process, as characterized with wide openness to stakeholders to participate within it (inclusive), the 
presence of forum as means of collaborating, and the presence of clear legal foundation and transparent process. Institutional design refers to the procedure and the basic rule of collaboration important to legitimate the collaborative process procedurally. Collaborative governance process should be transparent and inclusive because the process transparency will build trust in stakeholders. The leader asks the stakeholders to participate in good will negotiation and to explore collective compromise and gain. However stakeholders often enter into collaborative process with skeptic framework. Collaborative governance is consensusoriented, despite consensus not always achieved. The end problem encountered in institutional design is related to the use of time interval restricting discussion scope and weakening the sustainability of collaboration.

\section{3) Leadership}

Leadership is important to embrace, to empower, and to involve and to mobilize stakeholders in order to make the collaboration successful. High conflict and low confidence are incentives for participation; therefore collaborative governance can continue the intermediary service between stakeholders receiving service. The availability of leaders tending to be dependent is corresponding to the local condition. The implication is that the potentially effective cooperation is likely inhibited by poor leadership.

4) Collaborative process

Collaborative process consists of five stages running in a cycle: 1) consensusoriented face-to-face dialogue, 2) building trust within stakeholders, 3) stakeholders' commitment to collaborative process in the term of obedience to result of discussion, 4) sharing knowledge on joint mission, problem definition, and identification of common values, and 5) provisional result, meaning the output expected in collaborative process.

\section{Methodology}

This study was a descriptive research with a qualitative approach that can give complete description on the result of research. This research took place in Boyolali Regency, Central Java. In this descriptive qualitative research, the author used purposive technique. In the qualitative research, the author is the main instrument, helped with observation, interview, and documentation [9]. In analyzing data, the author used qualitative technique, primary data, and secondary data. Primary data was obtained from informant. Meanwhile, secondary data derived from documents in the form of notes, recording, image, and other materials. This research employed an interactive qualitative technique of analyzing data constituting sustainable, repeated, and continuous attempt. Meanwhile, the procedure of interactive data analysis model, according to Milles and Hubberman (1992), encompasses data reduction, data display, and conclusion drawing [7]. Data reduction is a process of selecting, determining attention to simplification and transformation of raw data resulting from the field notes. Data display is a set of information organized allowing for conclusion drawing and action taking.

\section{$3 \quad$ Finding and Discussion}

\subsection{Community Empowerment Process through Logistic Reinforcement}

This research was conducted because the author wanted to find out how independent the 
milk cow breeders are in the attempt of empowering community. Milk cow breeders are required to keep learning to solve any problems related to the milk cows raised. The problem the cattle raisers often encounter is related to cow's health and artificial insemination. In addition, working persistence is an indicator of milk cow breeders' independency. Persistence intended in this study is the persistence in feeding, in cleaning the stall, and in milking. Empowerment is defined as an attempt of improving knowledge, insight, and system for the sake of implementing the duty corresponding to respective professions. Furthermore, community empowerment includes: 1) an attempt of improving education through improving material, method, infrastructure, directed to an attempt of growing lifetime learning spirit and participation within community; 2) an attempt of improving accessibility to innovation source, funding source, product and equipment provider, and marketing agency; 3 ) an attempt of improving action into the better one; 4) an improving effort including developing partnership network; 5) an attempt of improving business; and 6) an attempt of improving income and; equally important, 7) environment improvement expected to support the realization of improved life for the people, including family. Good income level and environment can improve its life. A good life can be achieved if each member of community has independency to improve their powerfulness.

Community empowerment through reinforcing milk cow breeding logistic in collaborative governance perspective in Boyolali Regency is expected to help milk cow breeders involving: looking for superior milk cow embryo, obtaining good nutrition, its management and treatment. Such empowerment is conducted to promote and to improve economy and social status of milk cow breeders. Thus, empowerment through logistic reinforcement means to generate their resource, opportunity, knowledge, and skill to improve capacity in determining the future of milk cow breeders.

There are some indicators of community empowerment through logistic: 1) knowledge and skill improvement; 2) attitude improvement; and 3) breeders' health improvement. In the indicator of knowledge improvement, according to the informants interviewed, some training has been provided to equip them with knowledge. Knowledge was given by animal husbandry extension officer and facilitator. However, it has not run optimally yet because of limited budget and personnel. Therefore, the knowledge is considered as very inadequate, because the training is held only once a year. Considering all activities conducted, it can be seen that the improvement of breeders' knowledge has been conducted, but it is still inadequate as it is provided once a year and the breeders have not been able to absorb completely the knowledge given, because the facilitation is not conducted along the year.

Meanwhile, the indicator of attitude improvement is conducted or inserted into the improvement of knowledge and skill, but the improvement of entrepreneurship, professionalism, and independency has not been conducted specifically. Attitude improvement has not been conducted specifically, but it is conducted during the improvement of breeders' knowledge and skill. Thus, the result of breeders' changing attitude has not been perceived highly. Considering the result of interview conducted on the improvement of breeders' health, there has been no special treatment to breeders' health, but there has been special treatment to the cattle's health. There has been posyandu (integrated service post) service in the village or puskesmas (public health center) in the sub district for the breeders.

The development of milk cow and beef cattle breeding businesses in Boyolali Regency has been support by government, private, and universities, from fledgling, cattle feed, veterinary, marketing, and other institution, including capitalization to optimize the productivity and efficiency of sustainable cattle breeding business, as shown in the table below: 
Table 3. Data of Producer, Distributor of Cattle Feed and Self Mixing Cattle Breeder

\begin{tabular}{|c|c|c|c|c|}
\hline No & $\begin{array}{c}\text { Name of Producer, } \\
\text { Distributor of Cattle Feed } \\
\text { and Self Mixing Cattle } \\
\text { Breeders }\end{array}$ & $\begin{array}{c}\text { Cattle Feed/Feed } \\
\text { Material circulated }\end{array}$ & $\begin{array}{c}\text { Sale } \\
\text { Volume } \\
\text { (ton/year } \\
\text { ) }\end{array}$ & Note \\
\hline 1 & CV. Global Nutrisi & $\begin{array}{c}\text { Ruminant Cattle } \\
\text { Feed }\end{array}$ & 1,320 & Producer \\
\hline 2 & CV Perkasa & $\begin{array}{c}\text { Ruminant Cattle } \\
\text { Feed }\end{array}$ & 1,400 & Producer \\
\hline 3 & UD Sulur Tani & $\begin{array}{c}\text { Ruminant Cattle } \\
\text { Feed }\end{array}$ & 900 & Producer \\
\hline 4 & $\begin{array}{l}\text { PT. Andini Megah } \\
\text { Sejahtera }\end{array}$ & $\begin{array}{c}\text { Ruminant Cattle } \\
\text { Feed }\end{array}$ & 4,800 & Producer \\
\hline 5 & $\begin{array}{c}\text { PT Cepogo Agro } \\
\text { Lestari }\end{array}$ & $\begin{array}{c}\text { Ruminant Cattle } \\
\text { Feed }\end{array}$ & 3,600 & Producer \\
\hline 6 & KTT Sido Tani & Ruminant Cattle Feed & 960 & $\begin{array}{r}\text { Self } \\
\text { mixing }\end{array}$ \\
\hline 9 & $\begin{array}{l}\text { KTT Bina Usaha } \\
\text { Peternakan Modern }\end{array}$ & Ruminant Cattle Feed & 144 & $\begin{array}{r}\text { Self } \\
\text { mixing }\end{array}$ \\
\hline 10 & KTT Tunas Muda & $\begin{array}{c}\text { Ruminant Cattle } \\
\text { Feed }\end{array}$ & 30 & $\begin{array}{c}\text { Self } \\
\text { mixing }\end{array}$ \\
\hline 11 & KTT Sayuk Rukun & $\begin{array}{c}\text { Ruminant Cattle } \\
\text { Feed }\end{array}$ & 700 & $\begin{array}{l}\text { Self } \\
\text { mixing }\end{array}$ \\
\hline 12 & KTT Ngudi Santoso & $\begin{array}{c}\text { Ruminant Cattle } \\
\text { Feed }\end{array}$ & 250 & $\begin{array}{l}\text { Self } \\
\text { mixing }\end{array}$ \\
\hline 13 & Santoso & $\begin{array}{l}\text { Poultry and ruminant } \\
\text { cattle feed }\end{array}$ & 600 & PS \\
\hline
\end{tabular}

Source: Boyolali Regency in Number,2020

Notes:

KTT : Farmer and Cattle Breeder Group

PS : : Selfmixing Breeder

Animal husbandry sector of Boyolali Regency also has good potency. Villagers have cattle or livestock as secondary livelihood. The types of big cattle raised by people are cow, buffalo, horse, goat, sheep, and pig. The population of milk cow and beef cattle increases in the last 2 (two) years, the number of cow is 92,859 in 2018, and the number of beef cattle is 92,619 in 2017. Another cattle, milk cow, increases to 99,311 in 2018; buffalo increases from 737 to 745 in 2018; horse increases from 94,392 in 2017 to 95,428 in 2018. Meanwhile, the population of sheep increases from 48,987 in 2017 to 50,717 in 2018; and then that of pig increases from 6,054 in 2017 to 6,523. Despite insignificance, all cattle commodities increase in 2018, as shown in the table. 
Table 4. Population of Big Cattle in Boyolali Regency during 2017-2018

\begin{tabular}{crr}
\hline Commodity & $\mathbf{2 0 1 7}$ & $\mathbf{2 0 1 8}$ \\
\hline Beef cattle & 92,619 & 92,859 \\
Milk cow & 96,066 & 99,311 \\
Buffalo & 737 & 745 \\
Horse & 303 & 315 \\
Goat & 94,392 & 95,428 \\
Sheep & 48,987 & 50,717 \\
Pig & 6,054 & 6,523 \\
\hline
\end{tabular}

Source: Boyolali in Number, 2018

\subsection{Collaborative Governance in Community Empowerment}

Collaborative governance in governmental organization, particularly in the empowerment of milk cow breeders in Boyolali Regency, is the government's need today. There are some reasons underlying the collaboration between institutions. Collaborative governance does not appear suddenly but results from initiatives of many parties encouraging collaboration and coordination in solving the problems encountered by milk cow breeders through logistic reinforcement. Empowerment process can grow independency. The empowerment of milk cow breeders is the attempts of improving knowledge, skill, and ability in which supervision is conducted through various joint decisions; encouraging the growth of togetherness, the freedom to choose and to decide; reducing interdependency and creating mutually benefiting relationship between government and private.

Considering the elaboration above, collaborative governance is not given but builds on some aspects. The emergence of collaborative governance can be seen from the aspect of institution's need for establishing cooperation between institutions, due to respective institution's limited ability of organizing any programs/activities itself. In addition, collaboration also results from an institution's limited budget, so that collaborative budget comes from not only one institution but also other institutions involved in collaboration. Collaboration can be stated as the expansion aspect of governmental science, particularly in the presence of governance concept emphasizing on the participation of such actors as government, private, and community in the governance. Collaboration can also be an alternative to developing the participation of interest group and in the presence of managerial failure in an institution or organization. The complexity resulting, in its development, leads to interdependency between institutions and the increased demand for collaboration.

\subsection{Supporting and Inhibiting Factors}

Community empowerment through reinforcing milk cow breeder logistic in collaborative perspective in Boyolali Regency finds supporting and inhibiting factors. Meanwhile, the supporting factors are, among others: human resource of milk cow breeders as one of advantages with an ability of exploring opportunity in making breakthrough in the term of milk cow breeding. Human resource is the first and primary factor in an organization. Strategic and 
operational technical implementation should build on human resource, involving stakeholders of milk cow breeding such as cooperative institution, association, milk processing industrial, cow milk breeder, cattle breeding performer, animal husbandry service office, and financial institution. Another supporting factor is good participation of government and milk cow breeders, independency in milk cow management: 1) the presence of support from citizen, village government, and adequate facilities, 2) spirit of group members to keep developing, 3) cow feed can be obtained easily, and 4) strategic location.

Meanwhile, the inhibiting factors found in this study are, among others: the improvement of breeders' knowledge and skill, attitude, and health has been conducted, but it still inadequate as it is conducted once a year only and the breeders have not been able to absorb the knowledge completely, because facilitation is not conducted along the year. In addition, covid-19 pandemic condition makes some program not running maximally, despite the implementation of 3-M health protocol (mencuci tangan, memakai masker dan menjauhi kerumunan (washing hand, wearing mask, and avoiding crowd)). This stipulation forces the milk cow breeders to reduce the activities generating crowd. In other words, inhibiting factors affecting community empowerment program through reinforcing milk cow breeding logistic in collaborative governance perspective in Boyolali Regency, Central Java, are: 1) limited fund grant, and 2) limited worker/resource because most breeding businesses are managed by individual cow owners.

\section{Conclusion}

Considering the discussion related to the community empowerment through logistic in collaborative governance perspective, it can be concluded that empowering process is a way by which people, organization, and community are directed to be able to master their life. Milk cow breeders are required to learn solving any problems related to the milk cows raised. Working persistence is an indicator of milk cow breeders' independency. Persistence intended in this study is the persistence in feeding, in cleaning the stall, and in milking. The implementation of collaborative governance will provide an effective output when it performs based on the principles becoming the substance of collaborative activities. An indicator to measure successful collaborative governance is an interdependent network structure between one element and another collectively reflecting the physical elements of network handled. Interstakeholder collaboration is an inhibiting factor that non-state stakeholder will have real responsibility for the outputs of policy. Meanwhile, the inhibiting factor is related to training and skill program conducted once a year because of limited budget. Community empowerment through logistic emphasizes on appropriate physical movement process for goods and service, for the appropriate location at appropriate time, and condition expected, and giving big contribution to milk cow breeder community in managing and raising milk cows in Boyolali Regency. 


\section{References}

[1] Alsop, R. Bertelsen, F. M. Holland, J., Empowerment In Practice, 2006.

[2] Ambar Teguh S.., Kemitraan dan Model-Model Pemberdayaan. Yogyakarta:Gama Media, 2004.

[3] Ansell, C. \& Gash, A. Collaborative Governance in Theory and Practice. Journal of Public Administration Research and Theory: J-PART,Vol. 18(4), pp. 543-571, 2008.

[4] Chatarina Rusmiyati, Pemberdayaan Remaja Putus Sekolah. Yogyakarta: B2P3KS PRESS, 2011.

[5] Emerson, K. Nabatchi, T. Balogh, S., An Integrative Framework for Collaborative Governance. The Journal of Public Administration Resarch and Theory May 2, 2011.

[6] Mc Guire, M. Collaborative Public Management: Assessing What We Know and How We Know it. Public Aministration Review, Vol. 66, Special Issue: Collaborative Public Management, Pp. 33-34, 2006.

[7] Milles, Hubberman AM MB, Analisis data Pembangunan dan Pemberdayaan Masyarakat. Yogyakarta: Pustaka Pelajar, 1992.

[8] Moeljarto, Politik Pembangunan Sebuah Analisis, Konsep, Arah,dan Strategi. Yogyakarta: Tiara Wacana, 1993.

[9] Moleong, Lexy J., Metodologi Penelitian Kualitatif. Bandung: PT Remaja Rosdakarya, 2011.

[10] Sunit Agus Tricahyono, Pemberdayaan Komunitas Terpencil di Provinsi NTT. Yogyakarta: B2P3KS, 2008

[11] Syukur, S. H., Fanani, Z., Nugroho, B. A., and Antara, M., Empowerment of Livestock Farmer through Graduate Program to Build to Village on Dynamics of Beef Cattle Farmers Groups Level of Gaduhan Model. Journal of Natural Science Research. 4 (2): 107-112, 2014. 